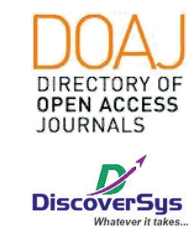

Published by DiscoverSys

\title{
Kualitas tidur pada sekuriti hotel dengan jadwal jaga malam di Kota Denpasar tahun 2017
}

\author{
Mia Felina Prasetya, ${ }^{1 *}$ Wira Gotera, ${ }^{2}$ Ida Bagus Putu Putrawan ${ }^{2}$
}

\section{ABSTRACT}

Background: Globalization forces some people to work at night, the time that should be dedicated for rest. Many health consequences have to be faced because of the night shift work, one of which is sleep quality. Aim: This study was performed in Denpasar City in 2017 to assess the sleep quality of night shift workers.

Methods: This study was a descriptive and observational study by using questionnaires. Population of this study was hotel security officer in Denpasar City with samples of 85 subjects.
Results: From 85 subjects investigated, $67.1 \%$ sample was categorized as poor sleep quality subjects and $32.9 \%$ was categorized as good sleep quality subjects. With total PSQI score above five as cut off, the mean was found at 7.26 and median was 7. In addition, the minimum PSQI score for this study was 2 and maximum PSQI score was 17.

Conclusion: It can be concluded that quality of sleep on night shift workers that being represented by hotel security, still belonged to poor sleep quality.

Keywords: hotel security, sleep quality, night shift worker

Cite This Article: Prasetya, M.F., Gotera, W., Putrawan, I.B.P. 2020. Kualitas tidur pada sekuriti hotel dengan jadwal jaga malam di Kota Denpasar tahun 2017. Intisari Sains Medis 11(2): 902-905. D0l: 10.15562/ism.v11i2.234

\section{ABSTRAK}

Latar belakang: Globalisasi telah memaksa sebagian orang untuk bekerja di malam hari, waktu yang sebenarnya adalah waktu untuk beristirahat. Dampak-dampak kesehatan pun bermunculan dikarenakan jadwal jaga malam ini, salah satunya adalah pada kualitas tidur.

Tujuan: Penelitian ini dilakukan di Kota Denpasar tahun 2017 untuk mengetahui gambaran kualitas tidur pada pekerja dengan jadwal jaga malam.

Metode: Penelitian ini menggunakan metode deskriptif observasional dengan pemberian kuesioner. Populasi penelitian ini adalah sekuriti hotel di Kota Denpasar dengan jumlah sampel 85 subyek.
Hasil: Dari 85 sampel yang diperiksa didapatkan 67,1\% sampel dengan kualitas tidur yang buruk dan kualitas tidur yang baik sebesar $32,9 \%$ dari sampel. Dengan skor total PSQI di atas lima sebagai batasan, telah didapatkan mean sebesar 7,26 dan median sebesar tujuh. Didapatkan juga skor PSOI minimum yang ada sebesar dua dan skor maksimum sebesar 17.

Kesimpulan: Kualitas tidur pada pekerja jadwal jaga malam yang diwakilkan oleh sekuriti hotel masih tergolong buruk.
${ }^{1}$ Program Studi Pendidikan Dokter, Fakultas Kedokteran, Universitas Udayana

2Bagian/SMF IImu Penyakit Dalam, RSUP Sanglah, Fakultas Kedokteran, Universitas Udayana

${ }^{*}$ Correspondence to: Mia Felina Prasetya, Program Studi Pendidikan Dokter, Fakultas Kedokteran, Universitas Udayana

Diterima: 08-04-2018 Disetujui: $15-06-2018$ Diterbitkan: 01-08-2020
Kata kunci: sekuriti hotel, kualitas tidur, pekerja jadwal jaga malam

Cite Pasal Ini: Prasetya, M.F., Gotera, W., Putrawan, I.B.P. 2020. Kualitas tidur pada sekuriti hotel dengan jadwal jaga malam di Kota Denpasar tahun 2017. Intisari Sains Medis 11(2): 902-905. D0I: 10.15562/ism.v11i2.234

\section{PENDAHULUAN}

Dewasa ini, seperti yang telah diketahui, dunia berkembang begitu pesat. Baik dari sisi teknologi, komunikasi, ekonomi, dan masih banyak lagi. Salah satu hasil dari perkembangan ini adalah globalisasi. Tidak hanya membawa pengaruh baik, pengaruh buruk pun tidak bisa dihindari oleh penduduk dunia. Pola hidup yang kurang sehat, munculnya jam kerja malam dan beban kerja yang meningkat, dan penyakit yang semakin kompleks adalah beberapa di antaranya. Oleh karena itu, penduduk dunia, baik dari negara maju maupun berkembang, tidak bisa lepas dari bahaya berbagai penyakit.

Terdapat beberapa parameter dalam kualitas tidur yang perlu diobservasi, seperti durasi tidur dan status ada atau tidaknya suatu gangguan tidur. ${ }^{1}$ Gangguan tidur sendiri dapat memengaruhi proses pemulihan tubuh dari masalah-masalah kesehatan, seperti luka yang didapat saat bekerja, kesehatan mental yang kurang baik, sering lupa, dan kemampuan berkonsentrasi yang menurun. Ini dapat mengurangi produktivitas pekerja. ${ }^{2}$ 
Kualitas tidur pekerja, terutama pekerja dengan jadwal jaga malam seperti pada sekuriti hotel, sering terabaikan oleh masyarakat maupun tenaga kesehatan. Padahal, performa kerja sering dipengaruhi oleh kualitas tidur. Performa kerja yang baik dan kualitas hidup yang baik akan bisa dicapai jika terdapat deteksi dan penanganan dini mengenai gangguan tidur. ${ }^{3}$ Oleh karena itu, diperlukan pengetahuan tenaga kesehatan mengenai kualitas tidur pada pekerja dengan jadwal jaga malam di Indonesia. Namun sayangnya, kualitas tidur para pekerja malam di Indonesia, terutama di Kota Denpasar, masih belum diketahui secara jelas dan perlu untuk diteliti. Inilah alasan mengapa penelitian akan gambaran kualitas tidur ini dilakukan.

\section{METODE}

Penelitian ini menggunakan metode deskriptif observasional dan pemberian kuesioner. Penelitian ini dilaksanakan pada tanggal $10 \mathrm{Mei}$ hingga 10 Agustus 2017 di area Kota Denpasar. Populasi dalam penelitian ini adalah semua sekuriti hotel yang memiliki jadwal jaga malam di Kota Denpasar tahun 2017. Penelitian ini menggunakan teknik consecutive sampling. Penentuan sampel pada penelitian ini menggunakan rumus sampel tunggal dengan jumlah sampel sebanyak 85 orang responden.

Sekuriti yang bersedia untuk ikut serta dalam penelitian diminta untuk menandatangani lembar persetujuan menjadi responden. Kemudian, sekuriti akan mengisi lembar kuesioner. Pada penelitian ini, instrumen penelitian yang digunakan adalah Pittsburgh Sleep Quality Index (PSQI) yang telah dimodifikasi oleh peneliti.

\section{HASIL DAN PEMBAHASAN}

Karakteristik responden yang mengikuti penelitian disajikan dalam tabel di bawah ini.

Rata-rata umur subyek pada penelitian ini adalah 34,5 tahun yang termasuk dalam umur produktif. Berdasarkan durasi jaga malam per bulan, ditemukan durasi jaga malam terbanyak adalah durasi $\leq 8$ jam. Berdasarkan kuantitas jaga malam per bulan, ditemukan kuantitas jaga malam terbanyak adalah $\leq 8$ kali. Dan berdasarkan kualitas tidur, kualitas tidur terbanyak adalah kualitas tidur buruk.

\section{Kualitas Tidur}

Kualitas tidur dapat dilihat berdasarkan komponen-komponen dalam kuesioner kualitas tidur. Komponen 1 (kualitas tidur subyektif) pada penelitian di RSUP Prof. Dr. R. D. Kandou Manado diketahui terbanyak pada kualitas tidur cukup baik sebanyak 44,23\%. ${ }^{4}$ Hasil tersebut serupa dengan penelitian ini yang juga mempunyai persentase terbanyak di kualitas tidur cukup baik, yakni sebanyak $80 \%$. Terkait komponen 1, penemuan ini kontras karena sebagian besar subyek menilai bahwa tidurnya dalam kategori baik. Hal ini bisa disebabkan oleh karena subyek tidak mengetahui komponen lain yang dinilai dalam kuesioner. ${ }^{5}$

Komponen 2 (latensi tidur) ditemukan terbanyak di 31-60 menit (50\%) pada penelitian sebelumnya. ${ }^{4}$ Sementara pada penelitian ini juga ditemukan terbanyak di 31-60 menit, yakni sebanyak 36,5\%.

Terdapat perbedaan pada komponen 3 (durasi tidur). Pada penelitian sebelumnya ditemukan bahwa durasi terbanyak adalah di bawah lima jam $(51,92 \%){ }^{4}$ Sementara pada penelitian ini, ditemukan durasi tidur terbanyak adalah di atas tujuh jam sebanyak $34,1 \%$. Hal ini bisa dikarenakan perbedaan tanggung jawab pekerjaan subyek penelitian.

Komponen 4 (efisiensi tidur) terbanyak ada pada rentang $>85 \%$ pada penelitian sebelumnya, yakni sebanyak 38,46\%. ${ }^{4}$ Pada penelitian ini juga didapatkan hasil terbanyak pada rentang $>85$, yakni sebanyak $76,5 \%$.

Terdapat perbedaan pada komponen 5 (gangguan tidur). Pada penelitian sebelumnya terdapat $59,62 \%$ responden mengalami gangguan tidur 1 sampai 2 kali dalam seminggu. ${ }^{4}$ Sementara pada penelitian ini, terdapat distribusi terbanyak pada gangguan tidur kurang dari sekali seminggu, sebanyak $58,8 \%$.

Komponen 6 (penggunaan obat tidur) memiliki distribusi terbanyak di penggunaan nol kali atau tidak pernah mengonsumsi obat tidur selama sebulan terakhir pada kedua penelitian. Pada penelitian sebelumnya didapatkan hasil sebesar $69,24 \%,{ }^{4}$ dan pada penelitian ini sebesar $97,6 \%$.

Komponen 7 (disfungsi siang hari) pada penelitian sebelumnya adalah dominan pada 1-2 kali disfungsi dalam seminggu, yakni sebesar 55,77\%. ${ }^{4}$ Sementara pada penelitian ini, ditemukan hasil yang sama dominan pada 1-2 kali disfungsi dalam seminggu, yaitu sebesar 45,9\%.

Pada penelitian ini didapatkan hasil bahwa kualitas tidur yang buruk pada kelompok umur 15-45 tahun sebanyak 67,6\%, sementara pada kelompok umur 45-64 tahun sebanyak 64,7\%. Terdapat sedikit perbedaan antara kedua kelompok umur, namun dapat dilihat bahwa persentase kualitas tidur yang buruk cenderung lebih besar di kelompok usia yang lebih muda, yaitu 15-45 tahun. Hasil ini sesuai dengan hasil penelitian di Amerika Serikat bahwa subyek usia tua dan paruh baya lebih 
Tabel 1 Karakteristik dasar subyek

\begin{tabular}{lc}
\hline Variabel & N \\
\hline Rerata umur (tahun) & 34,5 \\
Durasi Jaga Malam & \\
$\quad \leq 8$ jam & 72 \\
$\quad>8$ jam & 13 \\
Kuantitas Jaga Malam & \\
$\quad \leq 8$ kali & 67 \\
$>8$ kali & 18 \\
Kualitas Tidur & \\
Baik & 28 \\
Buruk & 57 \\
\hline
\end{tabular}

Tabel 2 Kualitas tidur berdasarkan umur

\begin{tabular}{lccc}
\hline & \multicolumn{2}{c}{ Kualitas Tidur } & \\
\cline { 2 - 3 } Umur & Baik & Buruk & Total \\
\hline $15-45$ tahun & $22(32,4 \%)$ & $46(67,6 \%)$ & $68(100,0 \%)$ \\
$46-64$ tahun & $6(35,3 \%)$ & $11(64,7 \%)$ & $17(100,0 \%)$ \\
Total & $28(32,9 \%)$ & $57(67,1 \%)$ & $85(100,0 \%)$ \\
\hline
\end{tabular}

Tabel 3 Kualitas tidur berdasarkan durasi jaga malam

\begin{tabular}{lccc}
\hline & \multicolumn{2}{c}{ Kualitas Tidur } & \\
\cline { 2 - 3 } Durasi Jaga Malam & Baik & Buruk & Total \\
\hline$\leq 8$ jam & $23(31,9 \%)$ & $49(68,1 \%)$ & $72(100,0 \%)$ \\
$>8$ jam & $5(38,5 \%)$ & $8(61,5 \%)$ & $13(100,0 \%)$ \\
Total & $28(32,9 \%)$ & $57(67,1 \%)$ & $85(100,0 \%)$ \\
\hline
\end{tabular}

Tabel 4 Kualitas tidur berdasarkan kuantitas jaga malam

\begin{tabular}{lccc}
\hline & \multicolumn{2}{c}{ Kualitas Tidur } & \\
\cline { 2 - 3 } Kuantitas Jaga Malam & Baik & Buruk & Total \\
\hline$\leq 8$ kali & $25(37,3 \%)$ & $42(62,7 \%)$ & $67(100,0 \%)$ \\
$>8$ kali & $3(16,7 \%)$ & $15(83,3 \%)$ & $18(100,0 \%)$ \\
Total & $28(32,9 \%)$ & $57(67,1 \%)$ & $85(100,0 \%)$ \\
\hline
\end{tabular}

toleran terhadap jadwal kerja malam hari. Subyek usia lebih tua memiliki respon yang masih lebih baik terhadap tidur yang kurang maupun gangguan ritme sirkadian. ${ }^{6}$ Subyek usia lebih muda juga memiliki kemampuan lebih rendah dalam menangani stres pekerjaan sehingga cenderung memiliki kualitas tidur yang buruk. ${ }^{7}$

Kualitas tidur yang paling buruk juga ditemukan pada kelompok subyek dengan durasi jaga malam delapan jam atau kurang dari delapan jam. Hasil ini kurang sesuai dengan kesimpulan pada dua hasil penelitian yang menyatakan bahwa durasi jaga malam yang lebih singkat lebih dianjurkan., ${ }^{89}$ Perbedaan ini bisa disebabkan oleh banyak faktor. Subyek dengan masa pengabdian lebih lama akan memiliki kualitas tidur yang lebih baik daripada subyek yang baru masuk bekerja. ${ }^{10}$ Faktor lain yang mempengaruhi adalah adanya masalah kesehatan seperti nyeri otot, obesitas, insomnia, gejala abdominal, dan depresi terkait dengan kualitas tidur yang buruk. ${ }^{8}$ Tekanan kerja yang berbeda juga menentukan subyek akan beresiko memiliki kualitas tidur yang buruk atau baik. ${ }^{7}$ Selain itu subyek dengan kualitas tidur buruk biasanya mengonsumsi makanan atau minuman berkafein. ${ }^{11}$ Rokok juga diketahui berpengaruh pada kualitas tidur dan fungsi sistem kardiovaskular. ${ }^{8}$ Kebiasaan terkait tidur seperti pencahayan kamar juga dapat memengaruhi kualitas tidur subyek. Paparan cahaya dapat menganggu ritme sirkadian yang mengakibatkan kualitas tidur yang buruk. ${ }^{5}$

Pada penelitian ini ditemukan bahwa kualitas tidur yang paling buruk didapatkan pada kelompok subyek yang memiliki kuantitas jaga malam lebih dari delapan kali. Hasil ini sesuai dengan kesimpulan pada penelitian di Iran, yang menyatakan bahwa subyek dengan frekuensi jaga malam yang lebih banyak mempunyai kualitas tidur yang lebih buruk. $^{12}$

\section{KESIMPULAN}

Berdasarkan hasil kuesioner PSQI, didapatkan kesimpulan bahwa sebagian besar kualitas tidur sekuriti hotel di Kota Denpasar tahun 2017 adalah buruk.

\section{DAFTAR PUSTAKA}

1. Thomaz M, Barone U, Wey D, Schorr F, Franco DR, Carra $\mathrm{MK}$, et al. Sleep and glycemic control in type 1 diabetes. 2015;(13):71-8.

2. Heo Y, Chang S, Park S, Leem J, Jeon S, Lee B, et al. Association between Workplace Risk Factor Exposure and Sleep Disturbance: Analysis of the 2nd Korean Working Conditions Survey. 2013;1-11.

3. Rajendran A, Parthsarathy S, Tamilselvan B, Seshadri KG, Shuaib M. Prevalence and Correlates of Disordered Sleep in Southeast Asian Indians with Type 2 Diabetes. 2012;70-6.

4. Thayeb RRTA, Kembuan MAHN, Khosama H. Gambaran Kualitas Tidur Pada Perawat Dinas Malam. J e-Clinic. $2015 ; 3$.

5. Fekedulegn D, Burchfiel CM, Charles LE, Hartley TA, Andrew ME, Violanti JM. Shift Work and Sleep Quality Among Urban Police Officers. J Occup Environ Med. 2017;58(3):20-4.

6. Press D. Shift work : health, performance and safety problems, traditional countermeasures, and innovative management strategies to reduce circadian misalignment. 2012;111-32.

7. Hee S, Jeffrey C, Pohl JM, Redman RW, Duffy SA. Factors Associated With Sleep Quality Among Operating Engineers. J Community Heal. 2013;597-602. 
8. Caruso CC. Negative Impacts of Shiftwork and Long Work Hours. 2015;39(1):16-25.

9. Kazemi R, Haidarimoghadam R, Motamedzadeh M, Golmohamadi R. Effects of Shift Work on Cognitive Performance, Sleep Quality, and Sleepiness among Petrochemical Control Room Operators. 2016;14(1):1-8.

10. Dong H, Zhang Q, Sun Z, Sang F, Xu Y. Sleep problems among Chinese clinical nurses working in general hospitals. 2017;(September):534-9.

11. Watson EJ, Coates AM, Kohler M, Banks S. Caffeine Consumption and Sleep Quality in Australian Adults. Nutrients. 2016;1-10.
12. Yazdi Z, Sadeghniiat-haghighi K, Loukzadeh Z, Elmizadeh K, Abbasi M. Prevalence of Sleep Disorders and Their Impacts on Occupational Performance: A Comparison between Shift Workers and Nonshift Workers. Hindawi Publishing Corporation; 2014;2014:10-4.

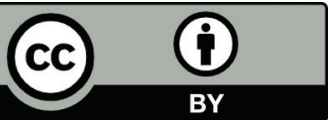

This work is licensed under a Creative Commons Attribution 